\title{
Magia y milagros de san Paulicio en Arderique (1517): el cadáver del santo, la pareja infecunda y el nacimiento heroico*
}

\author{
Magic and Miracles of San Paulicio in Arderique (1517): \\ the Holy Corpse, the Barren Couple and the Heroic Birth
}

\author{
Rafael Beltrán Llavador \\ Universitat de València \\ rafael.beltran@uv.es \\ ORCID iD: https://orcid.org/0000-0002-9346-3105
}

\section{RESUMEN}

Arderique es el título de un libro de caballerías castellano, anónimo, publicado en 1517 (Valencia, Juan Viñao). El artículo se centra en la función que desempeña en la obra un personaje, san Paulicio, cuyo auxilio se muestra decisivo en determinados momentos de la acción, empezando por el nacimiento de la heroína del relato. Se estudia el posible entronque de este Paulicio de la ficción con personajes históricos y con las vitae de santos eremitas, como san Pablo de Tebas. Y se estudian, asimismo, los motivos folclóricos que coinciden con las marcas de reconocimiento de la santidad de Paulicio: los leones rastreadores de su cadáver, las campanas tañendo solas y la carta agarrada por una mano cerrada. Los dos últimos, presentes también en la leyenda de doña Sancha de Aragón (contada por don Juan Manuel), pertenecen a la leyenda de otro santo eremita, san Alejo. Mientras que los libros de caballerías o las historias caballerescas del siglo XVI apenas aceptan santos ni milagros, en Arderique el hecho milagroso será un $a$ priori que determine la acción de los protagonistas.

Palabras Clave: Arderique; libro de caballerías; hagiografía; san Pablo de Tebas; san Alejo; don Juan Manuel.

\section{ABSTRACT}

Arderique is the title of an anonymous Castilian chivalry book, published in 1517 (Valencia, Juan Viñao). The article focuses on the role played by St. Paulicio, a character whose help is relevant in certain moments of the plot, starting at the birth of the heroine. I study the connections between this fictional Paulicio and some historical characters and vitae of hermit saints, such as

* El presente artículo forma parte del proyecto de investigación Parnaseo (Servidor Web de literatura española), FFI2017-82588-P (AEI/FEDER, UE), concedido por el Ministerio español de Economía, Industria y Competitividad. 
St. Paul of Thebes. I also analyze three folkloric motifs that coincide with the signs that reveal Paulicio's holiness: the lions tracking his corpse, the spontaneous tolling of bells, and the letter grasped by a closed hand. The last two motifs, which appear in the legend of Sancha de Aragón as well, belong to the legend of another hermit saint, Alexis. While the books of chivalry or knightly stories of the sixteenth century hardly accept saints or miracles, in Arderique the miracle determines the action of the protagonists.

Key words: Arderique; Books of chivalry; Hagiography; St. Paul of Thebes; Saint Alexis; don Juan Manuel.

\section{Argumento y edición De ARDERIQUe}

\subsection{El argumento}

Arderique es el título del libro de caballerías castellano, anónimo, que publicó Juan Viñao en Valencia en 1517¹. La Guía elaborada por Carpenter (1999: 11-42) ofrece un resumen detallado del argumento, y a ella y al propio texto, editado por la misma estudiosa (Carpenter 2000), remitiremos para cualquier detalle. La obra se divide en tres libros, pero puesto que nos vamos a centrar esencialmente en los siete primeros capítulos de su Libro Primero, daremos una sinopsis argumental muy sucinta de este Libro, seguida de otra, aún más breve, de los libros Segundo y Tercero:

Los capítulos iniciales detallan, a partir del reinado de Arturo de Bretaña, la genealogía de Leonor, de familia descendiente de linaje artúrico (I, 1-4). La concepción de Leonor es problemática, puesto que sus padres, Arnaldo y la hija del duque de Borgoña - de quien no sabemos el nombre-, en virtud de una promesa hecha por el duque a su padre antes de morir éste, no han podido contraer matrimonio hasta haber cumplido Arnaldo treinta años. Y una vez casados, transcurren, además, otros ocho años - que se suman a los anteriores de espera - sin lograr tener descendencia. Sin embargo, gracias a los rezos a san Paulicio, cuyo cadáver acaba de ser descubierto y exhumado en la Isla Joyosa, se alcanza finalmente el ansiado y feliz alumbramiento de un vástago, una niña que se llamará Leonor (I, 5-7). Al mismo tiempo, cerca de Roán, nace Arderique, hijo de un barón de la misma Normandía llamado Micer Borbón, cuando éste y su esposa, muy mayores, habían renunciado ya a tener descendencia. A los doce años Arderique se presenta en la corte de los duques, que lo acogen. A los pocos años el duque lo arma caballero. Leonor y Arderique, aunque todavía no han tenido oportunidad de encontrarse a

1 De esta edición, la única que conocemos que existiera, se conservan tres ejemplares: París, BNF, Rés. Y2 253; París, Bibl. Mazarine, Rés. 368; Viena, Biblioteca Nacional de Austria, sig. 27.N.24 (véase Lucía Megías 1999: 155-159; Canet 2017). El libro fue reeditado, casi cinco siglos después, por Carpenter (2000), en la prestigiosa colección de «Libros de Rocinante», auspiciada por el Centro de Estudios Cervantinos, casi paralelamente a la Guía (Carpenter 1999), en la colección complementaria. 
solas ni hablar, se enamoran el uno del otro. Arderique, junto a su inseparable amigo Alberto, sobrino de la duquesa, empieza a mostrar sobradas habilidades en las justas y en los torneos que disputa. En ellos va adquiriendo cada vez mayor fama, sobre todo en el torneo de Roán, donde viste una armadura especial, confeccionada en París. Allí puede encontrarse por fin a solas con Leonor, prometiéndose ambos amor y, además, podrá ser armado caballero por el duque de Normandía (I, 8-10). Arderique logra nuevos éxitos en un torneo en Brujas, adonde acude de incógnito con Alberto; permanece ocho meses en la corte del conde de Flandes, hasta que llega Beliseo, hija del conde de Mombriu, pidiendo ayuda contra Brunor el Fuerte (I, 11-15). Arderique, Alberto y el hijo del conde de Flandes acuden al castillo de Mombriu. Tras un feroz enfrentamiento entre Brunor y Arderique, éste le corta la cabeza al traidor; vencen luego a sus hermanos (Morgán y Galván) y se le restituye el condado a Beliseo. Arderique convence a ésta para que, aunque está enamorada de él, se case con el hijo del conde de Flandes, que se ha enamorado de ella. Ella no puede hacer más que obedecerle y, así, se celebran las bodas con largas y pomposas fiestas (I, 16-21). Mientras, a la corte de Roán han llegado noticias de la victoria de Arderique y de la belleza de Beliseo. Leonor, que no ha recibido carta de su amado en un año, se desespera ante la posibilidad de que la abandone por Beliseo; no come ni duerme, y cae mortalmente enferma. Cuando Arderique, avisado por Gostança, la doncella, regresa, Leonor acaba de morir; lee la carta que ella le había escrito, se desespera y pretende suicidarse, pero Gostança se lo impide; se encama entonces y enferma tan gravemente que está a punto de morir también él (I, 22-25). Por suerte, el duque de Normandía, desesperado por la muerte de su hija, ha rezado de nuevo a san Paulicio, haciendo promesa de enviar un año a su hija al monasterio si le devuelve la vida. Tras el rezo, Leonor, tres horas después de haber muerto, resucita milagrosamente y se cura. Arderique mejora también al conocer la buena noticia (I, 26-27).

En el Libro Segundo, Leonor parte hacia la Isla Joyosa para cumplir la promesa de su padre, pero acompañada por Arderique y Alberto, porque sólo se puede entrar en la isla por la fuerza de las armas. Tras una serie de enfrentamientos y aventuras llegan a Tiba, la capital de la Isla, donde son recibidos por el rey Héctor, quien convoca un torneo, que gana Arderique, aunque es herido gravemente. Arderique pasa por diversas aventuras, tanto de armas como amorosas. La principal, entre las primeras, es la que le enfrenta a Jorge Bello, de quien finalmente se hará amigo, y entre las segundas la del castillo del conde Archilago, donde su hija Blanca Flor, buena curandera (y vengativa hechicera, como veremos en el Libro Tercero) cuida a Arderique y se enamora locamente de él. Arderique, Alberto y Jorge Bello regresan a Tiba para ayudar al rey Héctor contra los longobardos. Arderique, que es nombrado capitán del ejército, vence al rey de éstos. Pero el hijo del derrotado, Godofré, y su sobrino Elim Lumbay acuden a Tarsia a enfrentarse con Arderique y Jorge Bello, quienes se proponen entonces la conquista del reino longobardo. Conquistan la ciudad de Plocia con una estratagema. Jorge Bello combate contra Godofré en feroz lucha y le corta la cabeza. Los de Tarsia han de rendirse a Arderique. Alberto se proclama rey de los longobardos y hay diferentes celebraciones, bodas y concesiones políticas. Parten de regreso a Normandía, donde esperan ansiosos el regreso de todos. En el Libro Tercero, en consejo convocado por el duque de Normandía, y pese al consenso entre los duques respecto a que Arderique era el mejor aspirante al matrimonio con su hija Leonor - y, además, el preferido de ella-, el caballero Febus, envidioso y poderoso, se opone y propone en cambio al duque de Clarencia, her- 
mano del rey de Escocia. El duque de Normandía acepta esta propuesta, tras ocho días de discusiones, y obliga a Leonor a acatar su mandato. Ante la negativa de ésta, el padre, encolerizado, está a punto de matarla con una daga y sólo la intervención de la madre la salva. El duque obliga a salir a Arderique de la corte, bajo pena de muerte, pero Leonor lo avisa y se comprometen ambos, entregándose anillos. Arderique y los suyos sacan secretamente a Leonor del palacio un día antes de la boda. El duque de Clarencia se marcha humillado. El duque de Normandía, avergonzado y sintiéndose culpable de todo, cae enfermo y muere. En las cortes generales de Roán, se reconoce a Arderique como duque de Normandía. Aunque un sacerdote los ha casado antes, la ceremonia de la boda se aplaza un año para mantener luto por la muerte del duque. El duque de Clarencia, su hermano, rey de Escocia, y el suegro de éste, rey de Norgales, declaran la guerra a Arderique. Se produce una gran batalla en la que son derrotados, pero Arderique se apiada del rey de Escocia y le permite regresar libre a su reino y manda, además, atender las heridas del duque de Clarencia. Su amigo Alberto, rey de los longobardos, acude a ayudarlo. Leonor da a luz un hijo, Galter. La hechicera Blanca Flor, mientras tanto, no ha olvidado a Arderique. Disfrazada y aceptada como paje suyo, realiza una serie de encantamientos: lo encierra en un castillo mágico, que desaparece por arte diabólico, y hace que Arderique se vuelva loco de amor por ella. Pero a un ermitaño, fray Antonio de Viterbo, se le revela el paradero de Arderique y proporciona a sus amigos los sortilegios para liberarlo. Rotos los hechizos, Blanca Flor y su tía, quienes invocan en vano los malos espíritus, serán quemadas públicamente. Arderique, de regreso a Normandía, es desviado por una tempestad a los mares de Escocia, donde el rey de Escocia y el duque de Clarencia, recordando la generosidad de su antiguo rival, le ayudan en todo. Ya en casa, Arderique y Leonor tendrán muchos hijos e hijas, de los que sólo se cuenta la historia del mayor, Galter. Éste, cuando cumple quince años, acude a París y a Alemania, donde lucha contra el duque de Estarlique, de linaje de gigantes, que pretende casar con la hija del Emperador. Como Galter lo vence, el Emperador le ofrece la mano de su hija. Y cuando su suegro muere, Galter le sucede como Emperador. Arderique y Leonor, ya de avanzada edad, viven el resto de sus vidas felices y descansan en la misma sepultura.

\subsection{La edición}

El hecho de que el libro exprese, desde su mismo título, que «es traducido de lengua estrangera en la común castellana», no tendría por qué obligarnos a pensar en una traslación de texto de otra lengua, si nos atenemos al uso frecuente en los libros de caballerías del conocido tópico de la falsa traducción (Marín Pina 1994). Sin embargo, los entronques explícitamente artúricos del principio de la trama, los nombres de muchos personajes, y las localizaciones y resonancias principales de la obra nos conducen a deducir que las fuentes son francesas y, en consecuencia, que el libro fue efectivamente traducido de otra lengua, con toda probabilidad a partir de un original francés ${ }^{2}$.

2 Eisenberg y Marín Pina (2000) no lo incluyen, de hecho, en su Bibliografía de los libros de caballerías castellanos, precisamente por considerarlo sin duda texto traducido; al 
Arderique es, sin duda, un libro de formación compleja. Dentro de una trama que aparentemente presenta pocas sorpresas, contiene algunos episodios, además de los que tratamos de examinar más a fondo, que requerirían atención más detenida que la que les podríamos conceder aquí. Pero volviendo al tema de la traducción, la tesis del original catalán o de la fuente catalana (que pudo partir a su vez de un original francés) cuenta con pruebas sólidas. El libro, en su versión castellana, la única que conocemos, se terminó de imprimir en Valencia, el 8 de mayo de 1517, tres meses después de haberse firmado su contrato de impresión ${ }^{3}$. Pero es incuestionable que, al menos cuarenta años antes, en 1477, circulaba por tierras valencianas, escrito en catalán, como «lo arderich e de la filla del rey de normandia» (Berger 1987: 474). Confirmaría esta versión en catalán la presencia de otro posible ejemplar (en este caso, transcrito como «Arderi»), que constaría entre los bienes de Martí Joan de Galba ${ }^{4}$. En fin, la presumible existencia de un texto catalán anterior no implica necesariamente que la obra no pudiera haber sido originalmente francesa (Wittlin 1993: 605).

Si la edición conservada de 1517 nada nos dice sobre el autor o posible traductor del Arderique, sí que nos proporciona, en cambio, antes de la Tabla capitular, y justificando la fe de erratas, el dato importante de que «El bachiller Juan de Molina [fue] corrector de las presente impressión, y traductor» (Carpenter 2000: 211). Juan de Molina, cuya figura como intelectual y traductor ha sido bien estudiada, fue un letrado originario de Ciudad Real, pero instalado en Valencia, en cuyos círculos literarios lo podemos encontrar con incesante laboriosidad durante un largo lapso de tiempo (entre 1515 y 1550) . Pérez Priego ha destacado su labor de «traductor de oficio, hábil romanceador, [que] concibe la traducción, no como una compleja labor filológica, ni como una inquieta creación artística, sino como una pura actividad vulgarizadora...»

contrario, lo ponen de ejemplo (al lado del Tirant, Palmerín de Inglaterra, Demanda del Santo Grial) de libros de caballerías traducidos (2000: 9). Véase la reseña de Cuesta (2003) a la edición del año 2000 de Carpenter.

${ }^{3}$ Berger (1987: 472-474). Véase una valoración de los datos, dentro de un conjunto más amplio de ediciones de libros de caballerías, en Lucía (1999: 155-159).

${ }^{4}$ Martí Joan de Galba recibió de manos de Joanot Martorell, antes de morir, en 1465, el manuscrito de su Tirant lo Blanc, que él mismo mandaría imprimir en 1490. En el inventario de sus bienes, fechado el 1 de abril de 1490, figura ese «Arderi», entre otros libros (como «lo Tirant», «Carles Maynes», «Marli» o «Anderino Mezquino»). Chiner (1996) propuso plausiblemente identificar el último de estos libros, «Anderino Mezquino» con Il Guerrin Meschino de Andrea da Barberino (Guarino Mezquino, en la traducción al castellano, más cercano a «Anderino»), sugiriendo que Joanot Martorell pudo haber conocido el texto en alguna versión, probablemente en el original italiano, pero tal vez incluso en traducción catalana o castellana. Se ha defendido la posibilidad de que Martorell pudiera, en efecto, haber conocido Il Guerrin Meschino, tratando de aportar alguna prueba más (Beltrán 2015).

5 Para la vida y obra del bachiller Molina, y en especial su labor como traductor, véase López Estrada (1952), Pérez Priego (1981), Montaner (1997: 47-76) y Arronis (2013). 
(1981: 39-40). En lo referido específicamente a literatura de caballerías, Molina intervino no solo en la edición de Arderique, sino también en la del Lepolemo o El caballero de la Cruz (Valencia, J. Jofre, 1521), obra atribuida al desconocido Alonso de Salazar ${ }^{6}$.

No sabemos hasta qué punto el apego al original limitaba las traducciones o correcciones de Molina, pero lo cierto es que su intervención en algunas obras fue a buen seguro mucho más allá de lo que hasta recientemente se consideraba. Así, Arronis (2013) ha demostrado que otra obra supuestamente traducida de Molina, el Vergel de Nuestra Señora, no se trata solo de una simple traducción - como se creía y como él mismo reconoce - de la Vida de la Sacratíssima Verge Maria, escrita por el valenciano Miquel Peres, sino de una verdadera y nueva composición. Tanto por esa cualidad recreadora o revisora, como por su evidente buen conocimiento del catalán y del castellano, es legítimo sospechar que su labor fuera más activa y creativa que de mero traslado literal, y que pudiera, si no componer, sí «recomponer» textos heredados, de manera que resultaran realmente originales.

Además del nombre de Juan de Molina, encontraremos que el «Prologo sobre la traducción y nueva impresión del dicho libro» se encuentra «dirigido al noble y muy virtuoso señor Hierónimo de Artés, doncel»; es decir, al mismo noble y poeta valenciano que firma sus versos al final del Claribalte, y que ha sido identificado con el mismo Jerónimo «de Aunés» autor de la traducción del Morgante (Valencia, Francisco Díaz Romano, 1533), adaptación en prosa del poema caballeresco del mismo nombre compuesto por Luigi Pulci .

Arderique, en fin, merece un estudio detallado y extenso, que asimile los muchos avances en la investigación sobre libros de caballerías de la época realizados en los últimos años, desde el muy estimable trabajo de recuperación y análisis del libro realizado por Carpenter (1999 y 2000).

\section{LAS CAUSAS DE INFECUNDIDAD EN EL LINAJE ARTÚRICO DE LEONOR}

Dada la extensión de la obra, nos hemos de detener casi exclusivamente en los primeros capítulos, y en concreto en los relacionados con las dificultades de los duques de Normandía - futuros suegros del héroe Arderique - para concebir una hija, Leonor. Son páginas en las que los motivos de tradición caballeresca se solapan con los de tradición hagiográfica, en una amalgama

${ }^{6}$ Alonso de Salazar aparece como autor en la primera edición del Lepolemo, pero desaparece en las siguientes. Juan de Molina contribuyó a la financiación de la primera edición de este libro («dando lo necessario para ello el bachiller Juan de Molina») y aparece como revisor en la segunda (1525): «fue mejorado [el libro] y de nuevo reconocido por el bachiller Molina» (Bognolo 2002 y Neri 2006: 7-8).

${ }^{7}$ La identificación ha sido propuesta por Haro Cortés (2010: XL-XLIII). 
repleta de escollos si queremos desentrañar sus entresijos. El propio nacimiento de Leonor y sus posteriores resultados — subordinados a los del héroe masculino - supondrán la redención del castigo de infecundidad que ha de padecer su padre, Arnaldo, por no haberse sabido rebelar a un injusto compromiso familiar de exagerada dilación de su matrimonio. La intercesión de san Paulicio romperá el tabú de la esterilidad en la familia y permitirá que esta, personificada en Leonor, y vivificada con la savia nueva de un caballero valioso, recupere el poder regio y el prestigio latente desde nada menos que su antepasado, el mítico rey Arturo.

\subsection{Orígenes artúricos: de Artús a Hisón}

El capítulo 1 del Libro Primero comienza, desde su mismo título, remontándose a «Cómo el rey Artús, desposeído de su reino de la Gran Bretaña por su sobrino Morderec, desapareció y se fue donde nunca lo vieron, y cómo los britanos eligieron nuevamente un duque que rigiese en su lugar». Se narra, en efecto, el resultado de la batalla de «Salbrí» (es decir, Salesbières o Salisbury), que había enfrentado al rey «Artús» con su sobrino traidor Morderec, conocido final - el episodio de desaparición del rey de Gran Bretaña marca la clausura del ciclo artúrico - del texto original de La mort Artu, que recogerá también la versión castellana de La Demanda del Santo Grial (1515). En Arderique, el rey «Artús» queda herido durante la batalla y su hermana «la hada Morgaina, que era nigromántica», se lo lleva en su barca.

Llama la atención el uso de las variantes «Artús» y «la hada Morgaina» en el texto. La variante "Artús» es poco habitual, si no rara, en los libros castellanos. En cuanto a «Morgaina» (sin artículo ni atributo), la encontraremos en el Baladro del sabio Merlín (1498) o, exactamente con el mismo sintagma de «la hada Morgaina», en el Tristán de Leonís publicado en 1501, donde sin embargo leemos siempre «Artur». Pero más significativa es la aparición de «la hada Morgaina» (aunque también junto a "Artur») en la tradición amadisiana, y en concreto en Esplandián, cap. 183. El de Esplandián es un precedente que podría no ser azaroso, sino, al contrario, condicionar en buena parte el sentido del inicio nuestro libro. Porque en las primeras líneas de Arderique, y a propósito de cómo Artús no murió, sino que escapó malherido y Morgaina «levole consigo tan secreta e cautelosamente que [...] se pudo saber cosa ninguna de su muerte o de su vida», dirá el texto: «Verdad es que todos tovieron por cierta opinión que la hada Morgaina lo avía escondido [a su hermano Artús] y tenía encantado, porque los traidores y desleales vasallos que contra él se avían rebelado fuesen punidos... » (Carpenter 2000: 6; cursiva nuestra). Pasaje que concuerda con el final de Esplandián, cuando la maga Urganda (nueva Morgana) somete a encantamiento por un tiempo indefinido a Esplandián y a toda la corte convocada en la Ínsula 
Firme, sumiéndolos inconscientes en un abismo abierto en la tierra por ella misma $^{8}$.

La clara filiación de este episodio de Arderique con Esplandián es importante, porque la idea del retorno o resurrección del rey lleva implícita en ambos textos, como en las versiones originales de la leyenda, el compromiso de no elegir rey hasta encontrar a alguien del nivel de Arturo9. La suspensión de funciones, tras el encantamiento colectivo (en Esplandián) o tras la desaparición de Arturo (en Esplandián y Arderique), es necesaria para entender en ambos textos la necesidad de rearme de la clase caballeresca ${ }^{10}$. El proyecto optimista de regeneración, lanzado hacia la progenie amadisiana en Esplandián, se quedará, sin embargo, como veremos, en el linaje artúrico de la casa de Normandía que se presenta en Arderique, dilatado a un lapso de largo tiempo (varias generaciones) de purgación de la culpa, hasta la llegada de Leonor. Y, tras ella, del héroe Arderique. Y si queríamos insistir en ese compromiso adquirido en Arderique de no elegir rey, sino esperar el regreso mesiánico del mismo, es porque ese precedente legendario determina absolutamente todos los acontecimientos que siguen y que tienen que ver con las dificultades en el

${ }^{8}$ Garci Rodríguez de Montalvo se preocupa de hacer bien explícita, para que el encantamiento tenga total justificación en el pasado legendario, su evidente relación con el episodio artúrico: «...donde todos aquellos grandes príncipes quedaron encantados sin les acompañar ninguno de los sus sentidos, guardados por aquella gran sabidora Urganda. Que, después de muy largos tiempos pasados, la hada Morgaina le hizo saber en cómo ella tenía al rey Artur de Bretaña, su hermano, encantado, certificándola que havía de salir y bolver a reinar en su reino de la Gran Bretaña, y que en aquel mesmo tiempo saldrán aquel emperador y aquellos grandes reyes que con él estavan a restituir juntos con él lo que los reyes christianos hoviessen de la Christiandad perdido» (2003 [cap. CLXXXIII]: 821).

${ }^{9}$ Mientras que la situación de latencia esperanzada está planteada en Esplandián, donde, pese a los muchos y valiosos sucesores de Amadís y Esplandián (Lisuarte, Galaor, Florestán, Agrajes, etc.): «...estos infantes, sabido por ellos en la forma que sus padres les fue quitada la luz del mundo, teniendo esperança en su tornada, pues que por el trago de la muerte aún no avían pasado, nunca consintieron que emperador ni reyes fuesen llamados...» (Rodríguez de Montalvo 2003 [cap. CLXXXIII] : 823); este mismo estado de compromiso anhelante («teniendo esperança») se repetirá en Arderique: «...Y a esta causa jamás han querido elegir entre sí rey ni señor que los rigiese ni governase, teniendo siempre esperança de aquél que tanto amavan y querían» (Carpenter 2000: 6).

${ }_{10}$ Algo que queda solamente implícito en Arderique, pero que estaba meridianamente señalado en el texto de Esplandián: «....siendo ya en la hedad perfecta, viéndose muy grandes y hermosos, deseando emplear su tiempo en actos de gran fama... [...] tornándose cada uno en su señorío, aviendo consideración de los tiempos passados en que sus famosos padres demandavan las aventuras, $[\mathrm{y}]$ tan altas cosas en armas avían fecho, y viendo cómo al presente todo avía perecido, no sabiendo qué hiziessen de sí, deseando mostrar sus grandes fuerças, experimentando la orgulleza de sus coraçones [...], de acuerdo de todos fue que aquellos tiempos olvidados por ellos ressuscitados fuessen, tornando al primero estilo, andando por sus tierras e por las agenas como caballeros andantes, y assí lo pussieron en obra» (Rodríguez de Montalvo 2003 [cap. CLXXXIIII]: 823-824). 
mantenimiento del linaje. En efecto, en el libro anónimo, para solucionar el problema de ausencia de Artús se convocan cortes en Londres, que eligen a un noble príncipe de la provincia de Gasca (tal vez Gasconia o Gascuña, o, más ampliamente, Aquitania) (I, 1). Este nuevo gobernador o duque de la Gran Bretaña, procedente de Francia, se casa con un dama de «la noble línea y sucesión» de Artús y el matrimonio tiene tres hijos y una hija.

Renovación del linaje, por tanto, pero nuevo enlace indirecto con el linaje artúrico. De los tres hijos varones, el mayor (no se dice su nombre) será señor de la Gran Bretaña, como sucesor primogénito; el segundogénito (queda igualmente sin expresar su nombre) hereda la provincia de Gasca; y el tercero, Hisón (el único cuyo nombre se menciona), quien «por juicio de todos en todo género de caballería sin comparación sobrepujava», hereda el ducado de Normandía. Por su parte, la hija casa con un noble de Londres. Con este Hisón se introduce ahora un motivo de fuerte raigambre bíblica, el de la últimogenitura ${ }^{11}$. Y se prioriza el papel del ducado de Normandía sobre los señoríos de Gasca y Gran Bretaña.

\subsection{El celibato de Arnaldo, la pareja infecunda y el nacimiento extraordinario}

Arnaldo tiene doce años cuando su madre muere prematuramente. Su padre, Hisón, no asume al parecer esa pérdida y jura no volver a casarse nunca más: «porque mucho amava a la duquesa, su mujer y señora defunta, hizo voto de jamás casarse con ninguna, como después lo cumplió». Pero no acabará ahí su duelo, sino que cuando se pone enfermo, hace llamar a Arnaldo a su lecho de muerte, le habla en privado durante nada menos que seis horas de sus responsabilidades frente a sus futuros súbditos en el ducado de Normandía, le da consejos y le hace prometer que se mantendrá casto y no se casará hasta cumplidos los treinta años de edad: «le tomó la fe que fasta que fuese de treinta años ni pudiese ni tomase mujer, ni se casase en ninguna manera porque esto era lo que más le cumplía». Arnaldo, obediente, acepta esa prohibición (I, 3). El ingrediente folclórico más arcaico se ha introducido en una narración hasta aquí verosímil de descendencia nobiliaria. Hisón parece intentar prolongar en su hijo Arnaldo, contra toda lógica natural, una decisión personal de auto-punición, haciendo recaer en culpa colectiva su duelo individual por la muerte temprana de su mujer. A efectos narrativos funcionales, esa interdicción causa o motiva una carencia (en términos de Propp) que será generadora de acción.

${ }^{11}$ Bien estudiada por Frazer (1993): Isaac, Jacob, Efraim (el nieto de Jacob, frente a su hermano mayor Manasés), el mismo José, penúltimo hijo (último, si descartamos a Benjamín), David, etc. 
El tema de la prohibición del matrimonio temprano para el hijo es ciertamente original (no lo sería tanto para una hija), si bien recuerda los pactos o acuerdos sobre matrimonios infantiles entre familias o castas, tabúes en determinadas sociedades. La decisión de Hisón al no asumir nuevas alternativas matrimoniales condena su propia naturaleza a la esterilidad y, lo que es peor, la de su hijo a la misma infecundidad y, en consecuencia, al peligro de desaparición del linaje. Es necesario contextualizar dentro del género caballeresco los motivos literarios que subyacen a ese tema de interdicción, así como al tema de las dificultades para engendrar al nuevo miembro de la familia, para entender más cabalmente el alcance del hallazgo del cadáver de Paulicio, el hecho crucial a partir del cual se podrá empezar a conjurar esa maldición.

En Arderique, como en sus congéneres Flores y Blancaflor o Partinuplés, nos encontramos con historias que traslucen las tensiones y dificultades en la época a la hora de mantener las ventajas que tradicionalmente representaba un matrimonio temprano, casi adolescente, pronatalista. Tensiones que activa la disfunción en el seno familiar de un padre excesivamente protector o, en términos modernos, castrante. El nuevo duque de Normandía, Arnaldo, supera célibe la barrera de los veinte años, y entonces los condes y barones le aconsejan con argumentos políticos y morales que se case, porque de no hacerlo el ducado corre peligro de quedar sin gobierno. Pero Arnaldo les contesta, arguyendo motivos estrictamente personales, que no puede «contradecir la última voluntad y mandamiento» de su padre y les pide paciencia, logrando convencerlos. Pasado el plazo autoimpuesto, nada más cumplir los treinta años - entonces sí-, reúne a los grandes de su señoría en Roán para decirles que se someterá a su voluntad casando con quien estimen más conveniente. Ellos acuerdan que la escogida sea la hija del duque de Borgoña. Los embajadores acuden al duque de Borgoña, quien acepta complacido la propuesta de matrimonio (I, 4). Se celebran las bodas en Roán, con toda la pompa requerida. Pero los efectos del estigma familiar — vinculados a una suerte de paganismo o descreencia - se presentarán ahora: «como Nuestro Señor quiere continuamente de su pueblo ser rogado, no quiso luego dar sucesión a aquellos siervos suyos que tanto desseavan; que ya eran pasado cuatro años y la duquesa no se empreñava» (Carpenter 2000: 11). Ese «quiere continuamente de su pueblo ser rogado» implica una identificación entre la fe religiosa y la lógica matrimonial. La ruptura de esa lógica significaría un regreso a la barbarie (el paganismo o la gentilidad).

Pese a las oraciones y plegarias a Nuestro Señor para obtener el «fruto de bendición y heredero de aquel señorío que tanta necesidad tenían», pasan otros cuatro años sin que estas sean oídas. Y eso que «no dexaron romería, cuerpo santo ni peregrinage que supiesen en el mundo, que no anduviesen o hiziesen andar por que Nuestro Señor, que siempre a los que humildemente lo llaman responde, les oyesse en aquella petición que tanto desseavan» (Carpenter 2000: 11). Pero al parecer los rezos no habían sido dirigidos al correcto destinatario. 
Afortunadamente, gracias a un acontecimiento externo, el descubrimiento de «un cuerpo santo» en la Isla Joyosa, señorío del rey Héctor (no se da la menor pista sobre dónde podía estar ubicado este reino), y a la intercesión de las plegarias a este santo, iban a poder finalmente los duques ganar el premio de la sucesión durante tanto tiempo anhelada (I, 5). Estamos aquí a las puertas del capítulo del hallazgo del cuerpo del santo taumaturgo, en el que habremos de detenernos.

La dificultad de concepción del héroe forma una parte esencial, como acontecimiento extraordinario, en la carrera del destino heroico en el libro de caballerías (Gracia 1991). El caso del propio Arderique, hijo de padres seniles, si bien mucho menos complejo que el de Leonor, entraría dentro de esta casuística $^{12}$. Precisamente lo llamativo de Arderique es que se da preeminencia narrativa a las dificultades en la concepción, pero no del futuro héroe, sino de quien será su mujer, Leonor. Prioridad cronológica y prioridad nobiliaria: ella procede del linaje de Arturo, como hemos visto; él es hijo de simples barones. Sin embargo, las dificultades en la concepción de Leonor acopian un conjunto llamativo de elementos extraordinarios, que culminarán en la mediación de san Paulicio.

Luna Mariscal (2011) ha examinado con profundidad los principales casos de infecundidad de la madre (o de ambos padres), que encontramos en numerosas historias caballerescas breves, todas ellas de origen francés, como Roberto el Diablo, Flores y Blancaflor, París y Viana, Oliveros de Castilla y Partinuplés, a los que podríamos sumar otros en libros de caballerías autóctonos más extensos ${ }^{13}$. Roberto el Diablo es quizá, de todos, el texto más edificante y explícitamente religioso. El padre de Roberto, Aubert, es, como el Arnaldo de Arderique, también duque de Normandía, y la madre es igualmente duquesa de Borgoña (hija del duque de Borgoña en Arderique). La concepción del niño tiene lugar tras diecisiete años de matrimonio de los duques. Desesperados ambos de esa carencia, Roberto será engendrado tras las maldiciones a Dios de su padre y las invocaciones diabólicas de su madre ${ }^{14}$. En Flores y Blancaflor,

${ }_{12}$ Como Isaac, hijo del centenario Abraham y la nonagenaria Sara, o Juan el Bautista, hijo de padres muy mayores, Isabel y Zacarías (en la versión del Evangelio de Lucas). Aunque las dificultades en la concepción de Arderique se despachan en apenas dos líneas: «en aquel tiempo que la muger del duque de Normandía se empreñó y parió, en aquel mismo tiempo concibió ella [la muger de Micer Borbón] y parió un hijo, con mucha alegría suya y de su padre, y no sin causa, porque como los dos ya fuessen de luenga edad y nunca otro esperaban aver» (Carpenter 2000: 14).

${ }^{13}$ Las referencias son siempre, en el caso de las historias caballerescas breves, a textos editados por Baranda (1995). Véase también, además del citado trabajo de Luna Mariscal (2011), para el tema de la concepción y nacimiento del héroe en textos de caballerías hispánicos, Lalomia (2012).

${ }^{14}$ El texto castellano ha sido estudiado, entre otros, por Cacho Blecua (1986) y Cortés Hernández (2008). Para la tradición francesa, véase Gaucher (2003). 
micer Persio y Topacia, padres de Blancaflor, se casan en Roma con bendiciones papales y cumplen sobradamente, por tanto, con todos los requisitos supuestamente necesarios para poder confiar en un fruto merecido. Sin embargo, este no llega. Frente a la persistente esterilidad, los padres se resignan a la providencia divina ${ }^{15}$. En París e Viana, la esterilidad afecta también a los padres de una de los protagonistas, de nuevo femenina, Viana, como en Arderique y Flores y Blancaflor ${ }^{16}$. Y el número de años de infecundidad (siete) viene explicitado, al igual que hemos visto en Roberto el Diablo (diecisiete) y Arderique (ocho). En Oliveros de Castilla y Artús de Algarve, también los padres de Oliveros, el príncipe de Castilla y la hija del rey de Galicia, padecen un sensible retraso en la llegada de progenie. De nuevo se explicita claramente la mediación de plegarias y limosnas, a cargo de la madre, que luego tendrán una función determinante en el desarrollo de la acción. Finalmente, en la versión castellana de Partinuplés, el engendramiento de la protagonista, Melior, es también debido a la esterilidad de su padre, emperador de Constantinopla («no podía aver hijos ni hijas»), quien tiene que acudir a una «mora encantadora» (algo que no está en el original francés) ${ }^{17}$.

En los libros de caballerías que se publican en el entorno espacio-temporal de Arderique, ya en el siglo XVI, seguiremos encontrando con frecuencia como premisa al nacimiento heroico los motivos de la esterilidad, la tardanza en el engendramiento del hijo o simplemente la senilidad de la pareja de los padres. Por ceñirnos a los casos de fechas más cercanas, en Floriseo, publicado en Valencia un año antes que Arderique, en 1516, también los padres tienen dificultades de concepción. Y las superan a base de rezos, que tendrán su recompensa. No resultará extraño que Floriseo, más adelante, acabe siendo un caballero especialmente preocupado por hacer servicio a Dios y por hacer cumplir

${ }_{15}$ No insistimos en el tema de la geminación, que hemos visto que se da igualmente en la pareja protagonista de Leonor y Arderique. Ni en la reduplicada alusión a la famosa pareja que en Arderique se hace con el personaje de la hechicera Blanca Flor, que se disfraza de paje, para estar con Arderique, y cambia su nombre justamente a Flores. Flores y Blancaflor, hijos nacidos el mismo día de mora y noble cristiana, respectivamente, constituyen una de las parejas más citadas de la tradición románica, y su historia seguirá siendo recordada en nuestra tradición escrita, a través de pliegos, y oral, a través del romancero. López Rodríguez (2010) confirma para el Flores de Flores y Blancaflor una condición de enfermo de amor hereos que estaría en las antípodas del desapasionado Arderique (como demuestra Lobato 2010), aunque se podría acomodar, en cambio, a la actitud amorosa irracional de la Blanca Flor / Flores de Arderique.

16 Véase el estudio de González (2014), con una bibliografía reciente sobre la versión castellana de la obra.

${ }^{17}$ Como interpreta Luna Mariscal (2011), puesto que el papel intermediario para la gestación de Melior lo desempeña una hechicera, la condición feérica determinará los atributos principales de Melior, que no estará caracterizada por sus virtudes cristianas (como en anteriores casos), sino por sus dotes mágicas. 
la ley divina allá donde vaya. También en Claribalte, publicado dos años más tarde que Arderique, en 1519, se da el motivo de las dificultades de engendramiento, aunque la descendencia llegará sin mediación extraordinaria de ninguna clase. En Lepolemo (1521), en fin, en la confección del cual intervino el mismo Juan de Molina, el corrector de Arderique, el arranque coincidirá más marcadamente, de nuevo, con una maldición familiar que impide que fructifique la sucesión.

Son muchas las ficciones medievales, comprobamos, en las que los argumentos despegan con las dificultades de un matrimonio para concebir. Y tales apuros no siempre están justificados por la senilidad. En las novelas de los siglos XIV y XV, con las que Arderique claramente se ha de vincular, nos hallamos ante la convivencia de rasgos folclóricos persistentes - muy enraizados, casi atávicos - y valores nuevos ${ }^{18}$. Y en el mismo Arderique, el hilo de los acontecimientos en el relato obliga a identificar claramente el ilógico celibato - la obligatoriedad de un matrimonio maduro, a los treinta años - de Arnaldo, padre de Leonor, con las dificultades de engendramiento de un sucesor. A diferencia de las historias breves examinadas, el relato trata de ofrecer una explicación «biológica» a la amenazante falta de fecundidad de la pareja. La culpa no es de la providencia divina, ni del destino, sino del error humano. Parece evidente que Hisón, el padre de Arnaldo, víctima de un estigma (o de un complejo de culpa), le había impuesto a su hijo una prohibición injusta, como si le achacara la desgracia de la muerte prematura de su esposa. Sin duda, una especie de maldición familiar se prolonga con Arnaldo, quien hereda la falta de responsabilidad política y la pusilanimidad de su padre. Estamos ante el peligro máximo para la nobleza en la ideología feudal: la extinción del linaje. Arnaldo no solo muestra exceso de docilidad al acatar el incompresible mandato castrante de su padre, Hisón, sino que, luego, dependiendo ya exclusivamente de sí mismo, se mostrará como un antojadizo gobernante. Arnaldo es endeble, mudable, indeciso, mentiroso, vengativo y cobarde $^{19}$.

${ }^{18}$ Lo que ha visto Lozano-Renieblas, refiriéndose al ciclo de novelas de mujer perseguida, podría perfectamente hacerse extensivo a todo un grupo de obras en las que también los tabúes más ancestrales (incesto, canibalismo, infanticidio, brujería...) «son sustituidos por otros más acordes con las leyes históricas. (...) La defensa de los valores de la familia monogámica se convierte así en el eje vertebral de estas novelas» (2003: 123).

19 Así, cuando Febus se le rebele — se oponga a la decisión de Arnaldo a la hora de casar a su hija-, declarando que nunca reconocerá como futuro señor a un simple caballero y vasallo (Arderique) y le amenace con que habrá guerra en el ducado si se produce el matrimonio, Arnaldo cede ante él y jura ante el consejo que casará a su hija con el poderoso duque de Clarencia, hermano del rey de Escocia. Y cuando Leonor se niega a obedecer, su padre está a punto de matarla, apuñalándola cobardemente, siendo ella salvada por la intervención de la duquesa. Arnaldo sigue haciendo caso a Febus, cuando acusa con alevosía a Arderique de traición, y por eso expulsa a este de la corte. Luego, se arrepiente y reconoce su error, pero no hace nada por reconducir la situación. Miente al prometido de 
Arnaldo, padre débil, muere habiendo sido mal hijo, porque ha acatado servilmente, sin asumir una personalidad suficientemente autónoma, una orden a todas luces incorrecta e injusta de su propio padre; pero, sobre todo, muere habiendo sido mal gobernante, porque se ha fiado de modo medroso de malos consejeros. Ha engendrado, sin embargo, a una heroína diametralmente opuesta a él, que redime su linaje, en la línea en que hemos visto que lo hacían Blancaflor, Viana e incluso la Melior del Partinuplés, personajes siempre femeninos subordinados luego en el relato al protagonismo de sus parejas masculinas respectivas, pero que actúan con inteligencia y sentido común para favorecer los triunfos de estas parejas. Leonor será decidida, obstinada y hasta rebelde, como en cierto modo - si bien en un papel algo secundario - lo es también su propia madre, la duquesa de Normandía, que gobierna con juicio y fortaleza tras enviudar. Eso sí, Leonor tendrá que neutralizar los peligros femeninos externos que amenazarán luego con romper su matrimonio (y la continuidad linajística tan costosamente lograda): peligros personificados por la figura de la hechicera Blanca Flor, que se convierte en una terrible oponente sexual desde mitad del Libro Segundo y a lo largo de todo el Libro Tercero. Aunque no hay rivalidad sentimental con Blanca Flor, al ser esta una hechice$\mathrm{ra}$, que se mueve en otro nivel de oposición ${ }^{20}$.

La función de Leonor es, por tanto, la habitual de las heroínas de las novelas tardo-medievales: hacer congruente la difícil tensión entre pasión amorosa y responsabilidad política mediante la solución del amor marital, conjurando primero el peligro de la imposición paterna injusta, y luego, en perfecta armonía con su pareja voluntaria y sensatamente elegida, las amenazas del adulterio, la bigamia y el repudio (Brown-Grant 2009). Las consecuencias de la prohibición de un matrimonio temprano han sido nefastas, pero una mujer «milagrosamente» nueva (literalmente nacida de un milagro), Leonor, permitirá la limpieza y regeneración del linaje, que se saldará a la larga incluso con un «hijo de bendición» libre ya de la losa del pecado familiar.

Leonor, cuando esta escapa un día antes de la boda, enviando a Febus con un ejército al castillo de Micer Borbón, padre de Arderique, para rescatar a Leonor. De hecho, cuando el duque de Clarencia se vaya de Roán sin despedirse, Arnaldo se siente arrepentido, avergonzado y rabioso, y reconociéndose culpable, enfermará y se dejará morir, aunque al final se redima reuniendo a su consejo y rogándoles a sus nobles que reconozcan a Leonor como legítima sucesora y a Arderique como legítimo marido.

${ }^{20}$ Quede claro que la iniciativa en la relación amorosa la lleva siempre Leonor, ya que el amor de Arderique nada tiene de pasional, sino que, al contrario, como ha visto perfectamente Lobato (2010), el héroe se deja llevar con total pasividad por la atracción física que produce en Leonor y por la conveniencia de un matrimonio de provecho para ambos. En este sentido, teniendo en cuenta el papel demoníaco que juega la oponente y lasciva Blanca Flor, las actitudes racionales de ambos se convierten en una especie de alternativa a la sinrazón del mal de amor que sufre Flores, en la popularísima historia de Flores y Blancaflor (véase supra, n. 15). 


\section{3. «DE UN CUERPO SANTO QUE FUE HALlado EN LA ISLA JOYOSA»}

\subsection{El hallazgo del «cuerpo santo» de Paulicio}

Era preciso explicar con algún detalle los precedentes del hallazgo milagroso. Porque la historia del descubrimiento del cadáver del santo se produce en un momento crucial del arranque de la trama, ofreciendo una salida al impasse de la infecundidad de los duques de Normandía. Habían pasado ya ocho años desde la tardía boda y la duquesa seguía sin quedar embarazada, como hemos visto. Un día el rey Héctor, señor de la Isla Joyosa, contempla desde una torre de su palacio cómo descienden del cielo dos lumbres resplandecientes que van a posarse sobre la montaña ${ }^{21}$. Se dirige a examinar de cerca el prodigio y encuentra en medio de las dos lumbres a dos grandes leones cavando en la tierra hasta desenterrar un cadáver:
...continuaron siempre en cavar hasta que de aquella huesa sacaron un cuerpo muerto con gran reverencia y acatamiento. Vestido de ropas de buriel, estava cu- bierto con un manto pardillo, de manera que de su persona no se mostrava cosa ninguna, sino sólo las manos y pies. E tenía en la mano una carta cogida. E como lo ovieron sacado de la huesa, fuéronse los leones tan mansos como si fueran las más simples ovejas del mundo. Y como el rey esto vio, estuvo muy maravillado, y descavalgó del cavallo, y quísose allegar al cuerpo para descobijarle [destaparle] la cara, mas no pudo. Y sintió que d'él salía maravillosa flagrancia y olor, y tentando otra vez llegarse a él, no pudo. E volviéndose a los que con él venían, les dixo:
- Cierto éste es un gran milagro que Nuestro Señor Dios, por aqueste santo cuer- po, quiere mostrar y que sea manifiesto a los hombres (Carpenter 2000: 11-12).

Al deducir que se tiene que tratar de un «milagro» que Dios quiere hacer «manifiesto»a los hombres a través de un «santo cuerpo», el rey Héctor manda llamar al obispo para que acuda, y que lo haga con toda la «devota procesión que pudiese». Pero hay un detalle ciertamente significativo: nada más partir el enviado del rey con el mensaje para el obispo, «todas las campanas de la ciudad començaron a tañer por sí mismas», fenómeno que produce lógicamente que «toda la gente fue muy maravillada y espantada». El obispo obedece el mandato regio y parte en procesión, como si se tratara de hacer una rogativa, «cantando a Nuestro Señor himnos y psalmos y acostumbradas loores, muy

${ }^{21}$ Se funden los motivos del astro-guía y el animal-guía, asociados a la formación de leyendas —en la terminología de Van Gennep (1982) — de tipo astronómico o de tipo zoomórfico, respectivamente. La Isla Joyosa de Arderique remite sin duda a la artúrica Isla de la Alegría y al Castillo de la Dolorosa Guardia (después de la Joyosa Guardia), tan popular entre las elites lectoras como para formar parte de la arquitectura de construcciones como la del castillo de Olite (Martínez de Aguirre 2013: 212-218). Las lumbres resplandecientes tienen que ver con los fenómenos meteorológicos que acontecen tras el nacimiento o muerte del héroe (Lalomia 2012). 
devotamente». El cuerpo, cubierto con un manto, solo dejaba ver, como leemos en la cita, los pies y las manos. Una de las manos, cerrada, aferra fuertemente una carta, que el obispo intentará quitarle, sin lograrlo. La carta revelará que se trata de Paulicio, que había vivido treinta años en penitencia en aquel lugar, apartado de todos, y que llevaba muerto unos quinientos años. Quieren llevar el cadáver del santo a la ciudad, pero no pueden. Así que tienen que hacer allí capilla primero, y monasterio después, donde el rey colocará a su propia hija como abadesa, instaurando unas selectivas condiciones de entrada para las monjas. Las noticias de los milagros que el «cuerpo santo» de Paulicio hacía en el monasterio llegan a Normandía. Los duques y todos en su señorío le rezan y la duquesa, que llevaba - recordemos - ocho años sin poder quedar embarazada, tras la insistencia en las plegarias, gracias a la intercesión de san Paulicio finalmente dará a luz a una hija, de nombre Leonor. Casi simultáneamente nace Arderique, hijo de micer Borbón, fruto de un matrimonio senil que tampoco esperaba ya descendencia.

\section{2. ¿Quién pudo ser el santo Paulicio?}

El pasaje anterior cuenta con múltiples motivos dignos de consideración, relacionados con la formación de leyendas que parten del descubrimiento milagroso de un lugar santo, hallazgo que justificará la fundación de un santuario. Pero ese extraño san Paulicio, ¿sería un santo real o es pura invención? Porque, por acostumbrados que estemos a onomástica extravagante en el santoral cristiano, Paulicio no es nombre conocido. Habría, sin embargo, varias posibilidades de identificación con algunos personajes históricos o legendarios. En primer lugar, nos moveríamos en el ámbito de los llamados «padres del yermo», o padres del desierto, eremitas en torno al siglo IV d. J. (san Antonio Abad, san Onofre, san Pablo de Tebas, Pafnucio, etc.). Carpenter señala el parentesco más evidente y plausible, que vincularía a Paulicio con san Pablo de Tebas, el reconocido legendariamente como primer ermitaño cristiano. En efecto, desde la Vita Pauli de san Jerónimo hasta la Legenda aurea, dos leones —como los dos husmeadores de Arderique - cavan la tumba para que tenga sepultura el cadáver de Pablo de Tebas, que acaba de fallecer en su soledad de eremita. San Antonio Abad los descubre, es testigo del milagro que implica a los animales reverentes y entierra él mismo el «cuerpo santo». En segundo lugar, siguiendo en parcelas vecinas del mismo campo hagiográfico, encontramos a otro personaje, Pafnucio (con cierta proximidad fonética con Paulicio), discutible históricamente, que supuestamente fue discípulo del mismo san Antonio Abad y gran defensor del cristianismo contra las doctrinas arrianas ${ }^{22}$.

22 Su principal misión fue poner por escrito la vida de san Onofre. Ahora bien, así como san Antonio había descubierto el cadáver de san Pablo gracias a dos leones que cavaban su 
Si no exigiéramos una fuente exacta, sino una simple relación temática, podríamos conformarnos con estos dos antecedentes hagiográficos, que coinciden con Arderique en la presencia nada habitual de leones auxiliares cavando una tumba. En ninguno de los dos casos, con todo, hay concurrencia estricta con el argumento del libro de caballerías, donde hemos visto que los leones no ayudan a enterrar el cuerpo recién muerto, sino que guían para que se encuentre el cadáver oculto en una tumba centenaria. Y, además, lo cierto es que se alude en Arderique a una históricamente plausible guerra de los normandos con los lombardos o longobardos, lo que nos obliga a desplazarnos desde el terreno de la hagiografía al de la leyenda. Recordemos, si examinamos el argumento de la obra, que Jorge Bello, enemigo del rey Héctor de la Isla Joyosa, es vasallo del rey de los «longobartes» o longobardos, que luego cobran verdadero protagonismo en el libro, y de quienes acabará siendo rey Alberto, el mejor amigo de Arderique. Tanto esa presencia como la de algún topónimo concreto nos conducen a especular con otros posibles antecedentes de san Paulicio, ligados a la tradición carolingia, puesto que los longobardos sufrieron sus derrotas principales contra los francos en el siglo VIII, primero con Pipino III, el Breve (714-768), quién sometió a tributo a su rey Astolfo (rey longobardo y rey de Italia, entre los años 749 y 756), y luego con Carlomagno (742-814), quien, tras haber buscado la alianza de su nuevo rey, Desiderio (rey entre 756-774), casando con su hija, acabaría repudiándola y derrotando a su antiguo suegro. Y baste notar que las campañas de Carlomagno continuaron contra los sajones durante décadas, buscando la colonización y cristianización de sus territorios paganos, y que culminarían con la coronación imperial, siguiendo, por tanto, parecido periplo al que recorrerá Arderique y completará su hijo Galter como Emperador de Alemania.

Partiendo de estos presupuestos históricos, no habría que descartar, entre los posibles antecedentes de Paulicio, a un personaje de existencia tampoco totalmente certificada, Paolo Lucio o Paoluccio Anafesto, considerado tradicionalmente como el primer $d u x$ de Venecia (c. 697 - c. 717), luchador contra los lombardos asentados al norte de Italia ${ }^{23}$. Y habría otros hipotéticos anteceden-

fosa, Pafnucio entierra el cuerpo de aquél, es decir, de san Antonio Abad, igualmente con la ayuda de otros dos leones. Véase, para las vidas de santos en la literatura española, el panorama de Baños (2003); específicamente para ermitaños, y en concreto san Pablo, Baños (2011). Véase, para san Onofre, con especial atención a las versiones catalanas, Pastor Briones (2012) y Escartí (2014).

${ }^{23}$ La etimología nos remite por igual camino, en principio, a un nombre latino (Paulucius) compuesto por otros dos: Paulus y Lucius, Paulo y Lucio. Licio, nombre griego, pero no latino, sería asimilación de Lucio. O también a Paulus + patricius (Gasparri 2011). Paolo Lucio habría sido un noble de Eraclea, elegido como líder hacia 697 para finalizar los conflictos entre los diversos tribunos que hasta entonces habían gobernado las diferentes zonas de la laguna veneciana, así como para coordinar la defensa contra los lombardos y los eslavos que se asentaron al norte de Italia (Gasparri 2004-2005). 
tes, si pensásemos en una contaminación en la trasmisión del nombre: Paulino por Paulicio ${ }^{24}$. Finalmente, si pensamos en la Normandía histórica — sin duda el ducado al que pertenecen los personajes principales del texto- $-\mathrm{y}$ buscamos las fundaciones originales de monasterios de monjes $-\mathrm{o}$ mejor, monjas - en el territorio, nos llamará especialmente la atención el relato de la fundación del monasterio de Pavilly (el topónimo procede del antropónimo Pauliaco, fácil metátesis con Paulicio) en Normandía (20 kms al norte de Ruán), fundación ligada a la llamada que san Filiberto, santo normando, realizó a la santa Austreberta, monja benedictina, para ser abadesa del mismo (Yepes 1609: s. p. [año 684]).

Muchas historias, espacios diversos y tal vez demasiado rebuscadas resonancias para este santo tan extraño y esquivo, como vemos. Ninguna es concluyente. El solo nombre de Paulicio es difícilmente identificable con un único antecedente (el más cercano, por homofonía, sería el $d u x$ de Venecia, personaje que poco tuvo de santo). Hay una fusión y confusión de alusiones que hacen prácticamente imposible asociar a nuestro personaje con un solo Paulicio. Esa tarea sería, en fin, presumiblemente banal en la pesquisa histórica, pero no deja de carecer de sentido en la literaria. Por lo que vale la pena perseguir, si no ya el rastro de su nombre - pues vemos que sus pistas conducen a vías ciegas-, sí algunas de las acciones del santo en la ficción.

\subsection{Los leones descubridores: tradición hagiográfica y caballeresca}

A diferencia de la nutrida presencia de actos de magia, magos o magas en libros de caballerías, la aparición de milagros o la presencia de santos - de intervenciones religiosas, en definitiva - no es absolutamente excepcional, aunque sí rara y llamativa. Hemos visto cómo el rey Héctor encuentra, en medio de dos grandes «lumbres» que como objetos volantes no identificados descienden del cielo, a dos feroces leones que cavan con afán en la tierra una honda fosa hasta desenterrar un cadáver:

E llegando allí vio en medio de aquellas dos lumbres dos grandes y muy fero[císs] imos leones que con las uñas y a muy gran priesa en tierra cavaron, y habían

${ }^{24}$ Aunque Paulicio sea repetida lectio difficilior y, por tanto, haya de ser mantenido como lectura. Se trataría de san Paulino de Rochester o de York ( $†$ 644), obispo de York, enviado por san Gregorio, en 601, para predicar la fe junto a san Agustín. Y de Paulino II patriarca de Aquilea, quien el año 568, bajo presión de las invasiones lombardas o longobardas, hizo trasladar la sede metropolitana a Grado, bajo protección de Bizancio, donde sería proclamado patriarca. La isla de Grado, en el golfo de Venecia, donde Paulino pone a salvo de los longobardos las reliquias, conserva una serie de sugerentes leyendas hagiográficas, empezando por las ligadas a la fundación del Santuario de Barban (Vocino 2015: 276-278). 
fecho una huesa muy honda, de altura de tres codos, cuanto él de lexos determinar podía. E quando vio tan fieros leones, ovo gran miedo, y no se ossó allegar a ellos. Mas, a la postre, cobrando coraçón, pensando que no podía ser sino algún milagro, se allegó muy cerca por ver lo que era. Mas los leones nunca cesaron de hazer su oficio, ni hizieron otro movimiento ninguno, más que si no ovieran visto a ninguna persona (Carpenter 2000: 11-12).

En muchos relatos de anacoretas aparecen con frecuencia no solo animales protectores o auxiliares (ofreciendo alimento $\mathrm{u}$ otro auxilio), sino bestias salvajes, sometidas milagrosamente al poder de Dios, animales que en ocasiones se llegan a convertir en atributos identificadores de santidad. El del animalguía, o animal que conduce a un lugar especial, maravilloso, es un caso particular. Un ciervo, un jabalí, un toro, un pájaro (variante zoomorfa del ángel o ángeles, que pueden aparecer en medio de estrellas o luminarias, como en el nacimiento de Jesús) pueden guiar hacia un lugar santo, cueva o ermita, donde se encuentren una imagen, unas reliquias, o un cadáver (García Rodríguez 1966). Quizás el caso más notorio, en nuestra literatura, sea el hallazgo de la tumba de san Antolín persiguiendo un animal, en este caso un jabalí. El motivo, que recoge, entre otros, el texto épico de las Mocedades de Rodrigo, serviría para justificar el traslado de reliquias del santo, en el siglo XI, a la diócesis de Palencia y llevaría a Deyermond (1969) a relacionar la autoría del texto de las Mocedades con la de un clérigo de esta diócesis ${ }^{25}$.

Gómez Moreno (2004: 255-256; 2008), al estudiar la hagiografía como clave poética para la ficción literaria, enumera y analiza una extensa serie de casos de impregnación de las leyendas heroicas — en la épica y en la novelaa partir de una o varias vitae de santos o santas, en algunas de las cuales aparecen leones domeñados o leones ayudantes. La aparición de leones-guía es más esporádica, pero tendría también sus precedentes hagiográficos. Carpenter, al estudiar el caso de san Paulicio, señala el parentesco con la vida de san Pablo el Ermitaño (Pablo de Tebas), que efectivamente incluye Gómez Moreno como ejemplo destacado en su lista. La relación es evidente, aunque en las versiones hagiográficas — desde su primera biografía, la Vita Pauli primi eremitae de san Jerónimo - es siempre san Antonio Abad quien se entera de la muerte de san Pablo y, cuando acude a la cueva que era su morada, se encuentra con dos leones cavándole la fosa en la que luego él mismo depositará el cadáver. Los leones de la hagiografía son auxiliares, por tanto, en la inhumación y no en la exhumación del cadáver, como ocurre en Arderique. Las similitudes, con todo, son palmarias: se trata en ambos casos de dos leones, que actúan abstraídos, con mansedumbre, dedicación, y «con gran reverencia y acatamien-

${ }^{25}$ San Antolín no entró, en cambio, en la nómina de mártires de la Legenda dorada, aunque sí, posteriormente, en la de los Flores sanctorum, como ha estudiado Cortés Guadarrama (2016). 
to» (Arderique), tanto en uno como en otro texto. El relato caballeresco mantiene la mezcla de extrañeza, admiración y maravilla que tendría la escena ${ }^{26}$.

\subsection{Las campanas tañendo solas y la carta en mano cerrada: tradición histórica (Sancha de Aragón) y hagiográfica (san Alejo)}

Sin embargo, ni el motivo de las campanas tañendo por sí solas, ni el del cadáver con la carta apresada en la mano con tal fuerza que es imposible de arrancar aparecen en las vitae de san Pablo o san Onofre, aunque ambos motivos tienen enorme relevancia en el relato de Arderique:

Estonces mandó a un cavallero, de los que allí eran llegados, que fuesse muy presto a la ciudad y dixese al obispo, de su parte, que con la mayor y más devota procesión que pudiese, viniese a aquel lugar. E assí el mensajero, sin ninguna dilación, lo hizo. E luego todas las campanas de la ciudad començaron a tañer por si mismas, de lo cual toda la gente fue muy maravillada y espantada, viendo cosa tan nueva y maravillosa como era aquélla. [...] E estonces dixo el rey al obispo que se allegase a aquel cuerpo sancto, y le tomase la carta de la mano, porque sin duda creía que leyéndola sabrían quién era. Estonces el obispo se allegó y quísole tomar la carta de la mano que tenía, y nunca se la pudo quitar. E queríale descubrir la cara y tampoco pudo. Estonces se quitó afuera, conosciendo no ser digno de tomarle la carta (Carpenter 2000: 12).

Las campanas tañen solas en toda la ciudad, causando el estupor de todos. Y cuando el obispo intenta tomar la carta identificadora del cadáver, no logra hacerlo. El obispo hace un alarde de humildad al reconocer su dignidad insuficiente, y manda entonces a un clérigo «de muy buena y sancta vida» que lo intente. El clérigo anónimo («el buen clérigo») se acerca al cuerpo, que «le tendió el braço y abrió la mano», permitiéndole tomar la carta. No solo eso, sino que nada impide que el mismo clérigo pueda destaparle la cara (algo imposible hasta ese momento), cara que se muestra sonrosada, «fresca y colorada», es decir, «como si fuera hombre vivo» (Carpenter 2000: 12). La carta, escrita como si se tratara de un lujoso manuscrito iluminado en pergamino («con letras de oro y de muy finíssimo azul iluminada»), permite saber «todo el discurso y fin» de la vida del ermitaño desenterrado, que hacía quinientos años que había fallecido y que había llegado a aquella isla por entonces desier-

${ }^{26}$ El rey Héctor haría el papel de san Antonio. Tebas podría corresponder a la ciudad de Tiba, que aparece en el capítulo de Arderique como ciudad principal de la Isla Joyosa, si se piensa que Anidos - Isla de Anidos se menciona como el nombre antiguo de la Isla Joyosa - corresponde al $\mathrm{A}<\mathrm{b}>$ idos egipcio, como propone Carpenter. De hecho, el motivo de los leones que ayudan a san Antonio Abad a cavar la fosa para Pablo el Ermitaño, reaparece luego en la Vida de Santa María Egipciaca, donde también un león ayuda al monje a enterrar a la santa (Baños 2011: 135). 
ta (solo habitada por leones, osos y otras fieras salvajes), para hacer «áspera penitencia», lo que había logrado durante treinta años. Finalmente, la carta declara el nombre del «santo ermitaño»: Paulicio.

Pues bien, encontraremos ambos motivos folclóricos, tanto el de las campanas tañendo solas, como el de la carta en mano cerrada, en la leyenda hagiográfica de san Alejo, como hemos de examinar más adelante. Pero reparemos antes en que, unidos y asociados a un personaje histórico, los podemos localizar también en un importante texto literario, revestido de interesados ropajes hagiográficos. Se trata de la mención de doña Sancha de Aragón, que hace el infante don Juan Manuel en el Libro de las tres razones o Libro de las armas. Se habla de doña Sancha, tía de don Juan Manuel (hermana de su madre Constanza), a propósito del matrimonio del rey Jaime I de Aragón con doña Violante, hija del rey de Hungría. Y de ella cuenta don Juan Manuel:

...la infanta donna Sancha, que nunca casó. Et oy dezir que muriera en el ospital de Acre o estava desconocidamente serviendo los romeros; et parésçeme que oy dezir o a la infanta donna Ysabel, fija del rey de Mallorcas, que fue la primera muger con que yo casé, o duennas de su casa, que quando esta infanta finó en Acre, en el ospital, que se movieron todas las campanas de la villa a tañer por su cabo, commo las tannen quando ay algún cuerpo finado, et veyendo las gentes cómmo las campanas tannían por su cabo, fueron preguntando quién moriera entonçe et non fallaron omne ni muger finado en toda la villa sinon una romera en el dicho ospital, et fallaron que tenía una carta en la mano; et quando la quisieron tomar para leer, non gela pudieron sacar de la mano fasta que vino y un gran perlado, non me acuerdo si oy dezir si fuera patriarca o obispo, mas bien me acuerdo que oy dezir que era perlado. E desque vio que la carta non ge la podien sacar de la mano, mandól en virtud de sancta obediencia que diesse la carta. Et ella, maguera era muerta más avía de xx oras e estava yerta, luego quel fue mandado por sancta obediencia, abrió la mano, et tomó el perlado la carta et leóla a todo el pueblo, et falló que dizía la carta cómmo era la infanta donna Sancha, fija del rey don Juaymes de Aragón et de la reyna donna Violante, su muger (Ayerbe-Chaux 1987: 47-48; la cursiva es nuestra).

Los historiadores no dan crédito, naturalmente, a la historia relatada por don Juan Manuel, aunque no se suele poner en duda la historicidad del viaje a Tierra Santa o de las acciones caritativas de doña Sancha, para las que el único testimonio, sin embargo, es la noticia que nos facilita el Infante en este texto. Don Juan Manuel rodea de vaguedad sus fuentes de información: «oy dezir», «non me acuerdo si oy dezir si fuera patriarca o obispo», etc. Como dice Riquer, «no deja de transparentar cierto escepticismo» (1956: 232). Pero lo importante para nuestra argumentación, en todo caso, no es esa historicidad de lo contado, sino la adscripción al hallazgo del cuerpo muerto de un personaje histórico notable (una infanta del reino de Aragón) de dos de los motivos folclóricos que hemos encontrado relacionados con un personaje ficticio, san Paulicio. Y efectivamente estos dos mismos motivos, el de la carta del cadáver 
y el de las campanas tañendo solas, que no se encuentran en ninguna de las versiones de la vida de san Pablo de Tebas, sí que se hallan en la leyenda de san Alejo, una de las más populares entre las numerosas vitae de santos medievales ${ }^{27}$.

Alejo, hijo del noble romano Eufemiano, renuncia al matrimonio y a las riquezas y marcha a Edesa, donde vive como mendigo en la iglesia de Santa María hasta que se hace pública su santidad. Vuelve entonces a Roma, donde nadie le reconoce, y vive diecisiete años bajo la escalera de la casa de su padre, llevando una vida ejemplar por su pobreza. Cuando se da cuenta de que va a morir, escribe una carta, en la que detalla los acontecimientos de su vida, que guarda en su mano. Al expirar, unas voces misteriosas exhortan a acudir al lugar donde ha sido enterrado. En dos de las tres versiones castellanas medievales conservadas del relato de su historia, se escucha una voz de los cielos alentando a la gente a acudir a ese sitio, al mismo tiempo que suenan las campanas de toda la ciudad. En una de esas dos versiones (ms. BNE, 9247), las campanas tañen solas («por su cabo», «por su cuenta»): «E aquella ora que el alma le salió del cuerpo moviéronse quantas canpanas avía en Roma por su cabo» (Vega 1991: 76). Obsérvese la literal identidad con lo expresado por don Juan Manuel cuando muere doña Sancha (en la cita anterior): «se movieron todas las campanas de la villa [Acre] a tañer por su cabo». En el mismo ms. 9247 de la BNE, otra voz les dirige a casa de Eufemiano. Encuentran allí a Alejo muerto, su cara brillando como el sol y exhalando olorosas fragancias (motivo típico del desenterramiento de santos, que se da también con san Paulicio). En la mano lleva una carta que ni su padre, ni el Papa ni el Emperador pueden coger, pero la mano se abre cuando lo intenta su fiel esposa Sabina. (En las otras versiones castellanas, el Papa y el Emperador o Emperadores rezan y la mano se abre). La carta revela en todas las versiones la personalidad del santo y narra su viaje a Edesa.

El relato que hace don Juan Manuel de la vida de su tía doña Sancha y el relato de la vida del noble y santo Alejo guardan francas coincidencias: ambos abandonan sus existencias cómodas, rodeados de riquezas, para pasar a llevar una vida humilde y anónima dedicada al cuidado de los pobres y los enfermos en Asia Menor (Sancha en Acre, Alejo en Edesa); la verdadera identidad de los dos es descubierta por medio de una carta reveladora hallada tras su muerte; y en ambos casos un hecho milagroso atrae la atención de las gentes tras su muerte (campanas con Sancha y voces —o campanas también— con Alejo).

27 Para los motivos folclóricos en el Libro de las tres razones, véase, en lo referente al tema aquí tratado, Deyermond (1982) y Ramos (1992). En cuanto a los orígenes y las distintas versiones peninsulares de La vida de san Alejo, partiremos siempre del estudio y edición de Vega (1991). Para un resumen sobre las traducciones europeas de la obra, véase Alvar (2010). 
En cuanto al segundo motivo, la carta identificadora en la mano del cadáver, Riquer lo relaciona con las narraciones épicas referentes a Roland y a su espada Durandarte. Intentan arrancar al cadáver de Roland la espada, pero no lo consiguen, hasta que Carlomagno le pide - y logra - que le devuelva la buena espada que otrora el mismo emperador le ciñera. Sin embargo, Riquer reconoce la poca importancia de esas posibles fuentes, al lado de la relevancia evidente de la vida de san Alejo ${ }^{28}$. En definitiva, y pese a que Riquer no menciona el ms. de la BNE de La vida de San Alejo en el que se señalan con claridad las campanas tañendo solas, concluye que la leyenda de la infanta doña Sancha se forma a partir de la adaptación de la hagiografía de san Alejo. Y nadie, a partir de su estudio, ha puesto en duda esa vinculación.

\section{San Paulicio, san Alejo y la intercesión necesaria para el destino HEROICO}

San Paulicio es un santo ficticio y el episodio del hallazgo de su «cuerpo santo» se crea a partir de previos episodios, extraídos principalmente de las vidas de san Pablo de Tebas y san Alejo: de la del primero se toma el motivo de los leones cavando la tumba; de la del segundo, los de las campanas que tañen solas y la mano cerrada, aprisionando una carta identificativa. Ahora bien, tanto este episodio como el propio papel auxiliar del santo a lo largo de todo el libro se integran en una trama caballeresco-sentimental cerrada, como las de Flores y Blancaflor - historia a la que se remite, presentando como antagonista de Arderique al personaje de Blanca Flor-, París e Viana, El conde Partinuplés, Clamades y Clarmonda, Enrique fi de Oliva, etc. Y lo cierto es que ese rol auxiliar condiciona el desarrollo y la resolución de muchos momentos de la historia de una manera que no se da en ninguno de estos otros relatos caballerescos, ni en ninguno de los libros de caballerías que conocemos, puesto que los libros de caballerías se mueven en una órbitas ficcionales que excluyen la intervención de los milagros (sustancialmente verdaderos), mientras que en Arderique el hecho milagroso - declaradamente milagroso, sin paliativos ni disfraces de maravilloso- es un a priori que determina la acción.

Milagroso es el hallazgo del cadáver de san Paulicio, que vuelve milagroso el nacimiento de Leonor. La intercesión de san Paulicio es especialmente lla-

${ }^{28}$ Se podría añadir a los textos aportados por Riquer que el motivo de la espada agarrada por la mano cerrada del cadáver, se encuentra en el cap. XL del Partinuplés, donde el protagonista consigue la de un cristiano que estaba enterrado en una mezquita y al que nunca se le había conseguido arrancar el arma (véase el texto, en la edición de Monzó 2013: 451-452). En la historia caballeresca el motivo entronca mejor con la leyenda de Arturo y la espada incrustada en la roca, que ya señaló Deyermond (1982) como antecedente para el Libro de las tres razones. 
mativa en su primera epifanía, la que hemos podido examinar, ligada a las leyendas de ermitaños. Pero se convierte, además, en una ayuda mágico-milagrosa permanente. Seguirá existiendo un vínculo directo entre las intervenciones del santo, a partir de las concesiones obtenidas a través del monasterio creado en su nombre, y la prosperidad del ducado, asociada a los triunfos de Arderique y a la continuidad del linaje de los duques. El santo no solo propicia que nazca Leonor, sino que en su segunda mediación, tras las plegarias y la promesa previa, logra que la misma Leonor resucite después de haber permanecido dos horas muerta. El duque cumplirá con la promesa y enviará a su hija a pasar un año en el monasterio de monjas creado para el culto del santo. Hay toda una descripción de la contemplación del cuerpo del santo y se insiste en la ofrenda que Leonor realiza, en joyas entregadas a la abadesa para el monasterio, para agradecerle su protección en el largo viaje a Tiba (I, 26-27). En el Segundo Libro - tercera intervención - se relaciona a san Paulicio con las voces celestiales y rezos que deshacen el maleficio de la anónima hechicera del castillo encantado, cuando Arderique está a punto de perder su virginidad (II, 9-10). Y se vuelve a aludir a san Paulicio cuando el rey Héctor construye una capilla para el rey de los longobardos y acude al monasterio a informar a Leonor de las victorias de Arderique (II, 22). Más adelante, este hace colgar sus armas delante del altar de san Paulicio (II, 24).

Esa tutela permanente de san Paulicio resulta excepcional, insistimos, si la comparamos con la notoria escasez de santos activos, milagros efectivos e ingredientes explícitamente religiosos en otros relatos caballerescos, tanto de los siglos tardo-medievales, como del XVI. En estos, si es que llega a insinuarse su presencia, se integran o sincretizan en la ficción como personajes o hechos maravillosos: el santo es un mago (o maga) y el milagro es magia siempre (en los casos extremos, magia negra, o diabólica). Es cierto que la presencia religiosa se asimila y no llega a desentonar en la trama de Arderique, donde acaba igualmente por diluirse, pero en ciertos momentos resulta disonante y, en todo caso, en términos generales, no termina de encajar, precisamente por esa rareza o excepcionalidad dentro del género.

Evidentemente, el nacimiento extraordinario de Leonor tendría que haber sido, en el esquema convencional, el de un protagonista masculino, marcado para un destino heroico por esos precedentes prenatales. De partida, hay una falta de causalidad entre la concepción extraordinaria o in extremis de Leonor, ayudada por la divinidad por intercesión de san Paulicio, y los hechos de armas posteriores del héroe Arderique. Sin embargo, y pese al acontecer estrictamente caballeresco de la peripecia, a partir del Libro Segundo, aunque ya no se mencione a san Paulicio, la trama insistirá en la vinculación religiosa del protagonista y su linaje, y lo hará a través de dos episodios fundamentales. El primero será el del enfrentamiento con Blanca Flor, que empieza siendo una simple pretendiente amorosa, pero al final —en una prolongación innecesaria de la historia, puesto que la pareja principal ya ha contraído matrimonio - ad- 
quiere los atributos de la bruja demoníaca y ha de ser combatida como tal ${ }^{29}$. La ayuda la presta fray Antonio de Viterbo, otro ermitaño santo (su relación con san Paulicio no es explícita, pero sí se sobreentiende), a quien en visión se le revela el paradero de Arderique y el uso que se debe hacer de unas reliquias para poder rescatarlo (III, 18).

El segundo será el de la pugna final de Galter, el hijo de Leonor y Arderique, con el gigantesco duque de Estarlique, otro episodio, prácticamente el último del libro, que resulta un evidente apéndice resuelto con precipitación y mal integrado - peor todavía que el anterior - en la historia de los hechos de Arderique y Leonor. En ese capítulo, en un combate sanguinario, precipitado y muy pobremente justificado, el contrincante, a medida que va perdiendo extremidades (el brazo, la pierna...), va sucesivamente renegando, primero de Dios, y luego de los santos, hasta que finalmente invoca la ayuda de Lucifer, proponiéndose como su siervo si la recibe. Naturalmente, Galter acaba cortándole la cabeza y logra así, con esa acción drástica, la mano de la hija del Emperador. El pasaje tiene mucho de gratuito en su exagerada truculencia, pero a la vez es revelador, pues significa un cierre perfecto - la lucha contra un verdadero ser diabólico-, si se piensa en el mantenimiento y culminación con cierto sentido de la potente intromisión religiosa que hemos ido analizando y por la que el libro venía apostando desde su principio.

En Arderique, la intercesión de san Paulicio determina las acciones excelentes en el futuro del héroe, casi al mismo nivel - aunque en un sentido totalmente antagónico - que la injerencia diabólica, antes de ser engendrado Roberto el Diablo (normando, como Arderique), habrá de condicionar y explicar ideológicamente todas las acciones perversas de este nada convencional protagonista de historia caballeresca, quien a la postre también acaba redimiendo a su linaje con su arrepentimiento y heroicidad. Los orígenes heroicos del normando Arderique, en las antípodas de los inicios del normando Roberto, pero habiendo de redimir en ambos casos los pecados de un linaje, representan en cierta manera su alternativa religiosa ortodoxa. La figura del sabio protector (mago o maga) en el libro de caballerías ha sido sustituida aquí, como hemos visto, por la del santo (san Paulicio) o el religioso (fray Antonio de Viterbo). San Paulicio solo podía actuar distanciadamente. Pero el santo de Viterbo transforma ya directamente el milagro en magia ${ }^{30}$.

${ }^{29}$ Como ha estudiado Cuesta (2014: 351-352), en muchos casos el mago antagonista del libro de caballerías reviste un carácter diabólico: ya sea por sus tratos con demonios familiares suyos (la Florisdelfa de Tristán el Joven); ya sea por sus vicios, que demuestran una posesión diabólica; ya sea por pactos diabólicos, como ocurre aquí con Blanca Flor, al ejecutar verdadera magia negra.

${ }^{30}$ Primero, se le revela en visión el paradero de Arderique, cuando este permanece raptado por Blanca Flor en su castillo encantado y no hay manera de encontrarlo. Y su función, a continuación, es idéntica a la del mago de libro de caballerías. A partir de su 
La absoluta originalidad de Arderique, dentro del género, al hacer de la intercesión de san Paulicio un motivo determinante para la historia - originalidad, a la vez que desajuste o disonancia-, vendría dada por el intento de mantenerse fiel a los ingredientes más arcaicos, épico-legendarios, de las fuentes remotas de la historia. Esas fuentes, que habrían de estar relacionadas con algún relato de fundación de monasterios de monjas en Normandía - como el de Pavilly, apuntado anteriormente, a propósito de los posibles orígenes del santo Paulicio-, remontarían a testimonios legendarios de época carolingia, el único tiempo en que los franceses y normandos (empezando por Carlomagno) luchan contra los lombardos, en Italia, y contra los británicos luego, con triunfos imperiales al final, los mismos que en definitiva nos muestra Arderique con la figura de Galter, el glorioso sucesor en el linaje. Sin embargo, la pretensión de hacer equiparables, a igual nivel, los auxilios maravillosos vinculados a las creencias religiosas cristinas (los milagros del santo Paulicio) con los ligados a la tradición literaria caballeresca (los de magos o magas), es una apuesta del relato de todo punto excepcional, que probablemente no fuera aceptada con complacencia por los lectores de la época.

En los libros de caballerías ciertamente era ya innecesaria la presencia de unos milagros «reales» o de unos santos plausibles o verosímiles, puesto que sus funciones las suplían mucho más lógicamente, dentro de las convenciones del género, las figuras perfectamente ajustadas, acomodadas y admitidas de los magos y las magas. Una vez desaparecidas para la literatura las vinculaciones — válidas en el momento de la épica fundacional — entre historia religiosa y relato legendario, y disipado por completo el poder taumatúrgico de los milagros, motivos folclóricos tan vigorosos como los de los leones-guía, las campanas tocando solas o la carta en mano cerrada habrían perdido gran parte de su valor, al encontrarse insertos en unas nuevas coordenadas de relato de aventuras caballerescas, de afirmación de vínculos matrimoniales y de regeneración de linaje, donde habían dejado de cumplir una función precisa o distintiva.

revelación, instruye a Jorge Bello para que libere a Arderique: habrá de atar a las dos hechiceras (tía y sobrina), y luego quitarle al héroe, para desencantarlo, los anillos y la piedra del embrujo, como hace la propia Urganda en Amadis de Gaula. Arderique se adscribiría, así, a la modalidad de libros de caballerías que presentan de manera «realista» el rechazo y castigo de la magia. Como señala Cuesta (2014: 365-366) para estas obras, «la persecución de la hechicería es [...] más abundante que en la literatura artúrica española, y el castigo de las encantadoras no se produce, como en aquella, tanto a manos de Dios como a manos de los hombres. Además, los aspectos más característicos de la nigromancia, como convocar a los muertos o a los demonios, aparecen descritos de forma explícita, cuando en las obras artúricas apenas existe descripción alguna...». 


\section{BIBLIOGRAFÍA CITADA}

Alvar, Carlos (2010). Traducciones y traductores: materiales para una historia de la traducción en Castilla durante la Edad Media. Alcalá de Henares: Centro de Estudios Cervantinos.

Arronis Llopis, Carme (2013). «Juan de Molina, autor - y no traductor- del Vergel de Nuestra Señora», Studia Aurea. 7, pp. 389-416.

Ayerbe-Chaux, Reinaldo (ed.) (1987). Don Juan Manuel, Cinco Tratados. Madison: Hispanic Seminary of Medieval Studies.

Baños Vallejo, Fernando Juan (2003). Las vidas de santos en la literatura medieval española. Madrid: Laberinto.

Baños Vallejo, Fernando Juan (2011). «El ermitaño en la literatura medieval española: arquetipo y variedades», en José Ángel García de Cortázar y Ruiz de Aguirre y Ramón Teja (eds.), El Monacato espontáneo: eremitas y eremitorios en el mundo medieval. Aguilar de Campoo: Fundación Santa María La Real, pp. 121-152.

Baranda, Nieves (ed.) (1995). Historias caballerescas. Madrid: Turner, 2 vols.

Beltrán, Rafael (2015). «De Guerrin Meschino a Tirant lo Blanc: el simbolismo de la Sibila narrativa y teatral», en Anna Maria Babbi y Vicent Josep Escartí (eds.), More about "Tirant lo Blanc». From the sources to the tradition / Més sobre el «Tirant lo Blanc». / De les fonts a la tradició. Amsterdam: John Benjamins, pp. 87-100.

Berger, Philippe (1987). Libro y lectura en la Valencia del Renacimiento. Valencia: Alfons el Magnànim, 2 vols.

Bognolo, Anna (2002). «El Lepolemo, Caballero de la Cruz y el Leandro el Bel», Edad de Oro. 21 , pp. 271-288.

Brown-Grant, Rosalind (2009). French Romance of the Later Middle Ages: Gender, Morality and Desire. Oxford: Oxford Univ. Press.

Cacho Blecua, Juan Manuel (1986). «Estructura y difusión de Roberto el Diablo», en Y.-R. Fonquerne y A. Egido (eds.), Formas breves del relato (Coloquio Casa de Velázquez-Departamento de Literatura Española de la Universidad de Zaragoza. Madrid, Febrero de 1985). Zaragoza: Casa de Velázquez y Departamento de Literatura Española de la Universidad de Zaragoza, pp. 35-55.

Canet, José Luis (ed.) (2017). Tipobibliografia valenciana siglos XV y XVI [Base de datos]. Accesible en: <http://parnaseo.uv.es/tipobibliografia/Tipobibliografia.html> [Última consulta: 30/05/2017]

Carpenter, Dorothy Molloy (1999). Arderique (Valencia, Juan Viñao, 1517). Guía de lectura. Alcalá de Henares: Centro de Estudios Cervantinos.

Carpenter, Dorothy Molloy (ed.) (2000). Arderique. Alcalá de Henares: Centro de Estudios Cervantinos.

Chiner Gimeno, Jaume (1996). «De Guarino mezquino al Tirant lo Blanch: una nova hipòtesi sobre l'origen de l'onomàstica del cavaller bretó», en IV Congrés d'Història i Filologia de la Plana. Nules: Ayuntamiento, pp. 209-216.

Cortés Guadarrama, Marcos (2016). «Fuera del canon de la Legenda aurea: la vida de San Antolín en los Flores sanctorum castellanos medievales», Archivum. LXVI, pp. 7-44.

Cortés Hernández, Santiago (2008). «De Roberto el Diablo a Hellboy: dinámica narrativa de un héroe de la Edad Media al cómic», Revista de Literaturas Populares. VIII, pp. 376-409.

Cuesta Torre, María Luzdivina (2003). «Reseña de: Arderique (Valencia, Juan Viñao, 1517), ed. Dorothy M. Carpenter (Alcalá de Henares, CEC, 2000)», Bulletin of Hispanic Studies. 80, pp. 418-420. 
Cuesta Torre, María Luzdivina (2014). «Magos y magia: de las adaptaciones artúricas castellanas a los libros de caballerías», en Alberto Montaner y Eva Lara Alberola (eds.), Señales, portentos y demonios: la magia en la literatura y la cultura españolas del Renacimiento. Salamanca: La SEMYR, pp. 325-366.

Deyermond, Alan (1969). Epic Poetry and the Clergy: Studies on the «Mocedades de Rodrigo». Londres: Tamesis.

Deyermond, Alan (1982). «Cuentos orales y estructura formal en el Libro de las tres razones», en Don Juan Manuel. VII Centenario. Murcia: Universidad de Murcia - Academia Alfonso X el Sabio, pp. 75-88.

Escartí, Vicent Josep (ed.) (2014). Sobre la vida i els miracles de Sant Onofre Anacoreta, segons la versió anónima publicada a València, a començaments del segle XVI. Valencia: Espirelius.

Eisenberg, Daniel y M. ${ }^{a}$ Carmen Marín Pina (2000). Bibliografía de los libros de caballerías castellanos. Zaragoza: Prensas Universitarias de Zaragoza.

Frazer, James G. (1993). El folklore en el Antiguo Testamento. Madrid: FCE.

García Rodríguez, Carmen (1966). El culto de los santos en la España romana y visigoda. Madrid: CSIC.

Gasparri, Stefano (2004-2005). «Roma y los Longobardos», Anales de Historia Antigua, Medieval y Moderna. 37-38, pp. 31-48.

Gasparri, Stefano (2011). "Anno 713. La leggenda di Paulicio e le origini di Venezia», en Uwe Israel (ed.), Venezia. I giorni della storia. Roma: Viella, pp. 27-45.

Gaucher, Élisabeth (2003). Robert le Diable. Histoire d'une légende. París: Champion.

Gómez Moreno, Ángel (2004). «La hagiografía, clave poética para la ficción literaria entre medievo y barroco: con no pocos apuntes cervantinos», Edad de Oro. 23, pp. 249-278.

Gómez Moreno, Ángel (2008). Claves hagiográficas de la literatura española (del «Cantar de Mio Cid» a Cervantes). Frankfurt - Madrid: Iberoamericana - Vervuert.

González, Cristina (2014). «Identidad y conflicto en París y Viana: ¿sería París judío?», Tirant. 17, pp. 265-274.

Gracia, Paloma (1991). Las señales del destino heroico. Barcelona: Montesinos.

Haro Cortés, Marta, (ed.) (2010). Morgante (Libro I). Alcalá de Henares: Centro de Estudios Cervantinos.

Lalomia, Gaetano (2012). «La concepción y el nacimiento del héroe (T500-599): un motivo con variaciones», Revista de poética medieval. 26, pp. 169-186.

Lobato Osorio, Lucila (2010). «El caballero Arderique: entre el amor desapasionado y sus tres matrimonios con la misma dama», en Expresiones de la cultura y el pensamiento medievales. México: El Colegio de México - UNAM - UAM, pp. 327-341.

López Estrada, Francisco (1952). «Una edición desconocida del Enquiridion (Valencia, 1528, por Costilla)», Revista de Archivos, Bibliotecas y Museos. 58, pp. 449-463.

López Rodríguez, Irene (2010). «La enfermedad de amor en Flores y Blancaflor», Lemir. 14, pp. 69-87.

Lozano-Renieblas, Isabel (2003). Novelas de aventuras medievales. Género y traducción en la Edad Media hispánica. Kassel: Reichenberger.

Lucía Megías, José Manuel (1999). Libros de caballerías castellanos en las bibliotecas públicas de París: catálogo descriptivo. Alcalá de Henares: Universidad de Alcalá.

Luna Mariscal, Karla Xiomara (2011). «De la mujer infecunda a la madre del héroe. El motivo de la dificultad en la concepción en algunas historias caballerescas breves», Atalaya. 12. Accesible en: < https://journals.openedition.org/atalaya/733 >

Marín Pina, M. ${ }^{a}$ Carmen (1994). «El tópico de la falsa traducción en los libros de caballerías españoles», en María Isabel Toro Pascua (ed.), Actas del III Congreso de la Asociación 
Hispánica de Literatura Medieval (Salamanca, 3 al 6 de octubre de 1989). Salamanca: Departamento de Literatura Española e Hispanoamericana, Universidad de Salamanca, vol. II, pp. 541-548.

Martínez de Aguirre, Javier (2013). «Lancelot en Olite: paradigmas arquitectónicos y referentes literarios en los palacios de Carlos III de Navarra (1387-1425)», Anales de Historia del Arte. 23, número especial (II), pp. 191-218.

Montaner, Alberto (ed.) (1997). Libro de los dichos y hechos elegantes y graciosos del sabio Rey don Alonso de Aragón, según la traducción del bachiller Juan de Molina. Edición facsimilar de la obra de Antonio Becadelli. Zaragoza: Cortes de Aragón.

Monzó, Clara (2013). «Transcripción de El conde Partinuplés», Tirant. 16, pp. 409-468.

Neri, Stefano (2006). Lepolemo (Valencia, Juan Jofré, 1521). Guía de lectura. Alcalá de Henares: Centro de Estudios Cervantinos.

Pastor Briones, Vicent (2012). «La "vita aspera" de sant Onofre: anàlisi i edició», en Miscel-lània Albert Hauf (Estudis de llengua i literatura catalanes). Barcelona: Publicacions de l'Abadia de Montserrat, vol. 4, pp. 5-30.

Pérez Priego, Miguel Ángel (1981). «La obra del bachiller Juan de Molina, una práctica de traducir en el Renacimiento español», 1616: Anuario de la SELGYC. 4, pp. 35-43.

Ramos Nogales, Rafael (1992). «Notas al Libro de las armas», Anuario Medieval. IV, pp. 179-192.

Riquer, Martín de (1956). «La leyenda de la infanta doña Sancha hija de don Jaime el Conquistador», en Homenaje a Millás-Vallicrosa. Barcelona: CSIC, vol. II, pp. 230-241.

Rodríguez de Montalvo, Garci (2003). Las Sergas de Esplandián, ed. Carlos Sainz de la Maza. Madrid: Castalia.

Van Gennep, Arnold (1982) [1912]. La formación de las leyendas. Barcelona: Alta Fulla.

Vega, Carlos Alberto (ed.) (1991). La «Vida de San Alejo»: versiones castellanas. Salamanca: Universidad de Salamanca.

Vocino, Giorgia (2015). «Les saints en lice: hagiographie et reliques entre Cividale et Grado a l'époque carolingienne», en Ph. Depreux, F. Bougard y R. Le Jan (eds.), Compétition et sacré au Haut Moyen Âge: entre médiation et exclusion. Turnhout: Brepols, pp. 273-294.

Wittlin, Curt (1993). «Dels manuscrits a l'edició: el Tirant, elaborat per Martorell el 1460 usant materials preexistents, revisat després en "valenciana prosa" per Galba», en Actes del Symposion «Tirant lo Blanc». Barcelona: Quaderns Crema, pp. 605-633.

Yepes, Antonio (1609). Coronica General de la Orden de San Benito, Patriarca de Religiosos. [Reino de Navarra]: Matías Marco Impressor, tomo II.

Fecha de recepción: 15 de junio de 2017.

Fecha de aceptación: 29 de diciembre de 2017. 